\title{
CTPATE[ИJE ФИMMCKOГ
}

МИНИМАТИЗМАИ
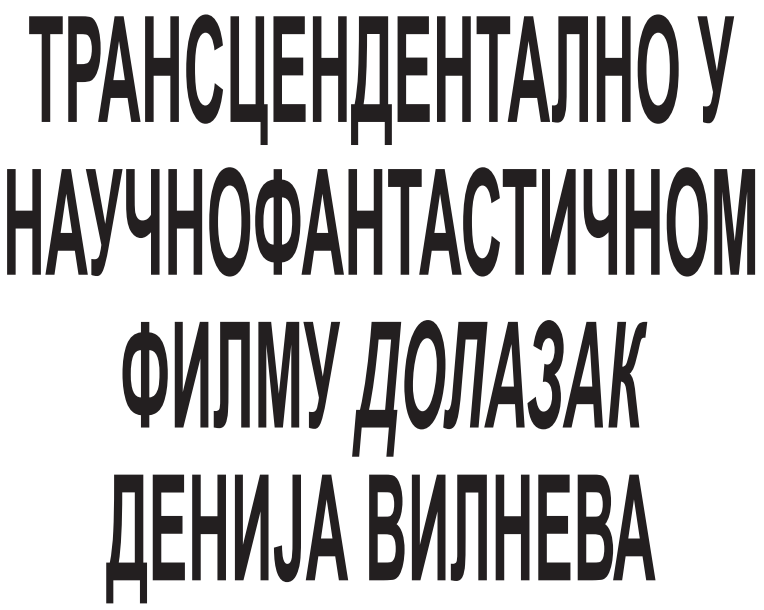

Сажетак: Научна фантастика као филмски жанр неретко примењује стратегије минимализма - у елементима као што су наративна структура, одабир планова, покрети камере, композиција кадра, осветљене и боја, костим и сиенографија, и звучна нараиија, примена минималистичких техника сведочи о трансценденталном стилу, схваћеном онако како то наводи Пол Шредер седамдесетих у својој истоименој студији (иако се она сама не бави овим жанром). Онтолошка питања која постављају СФ драме као што су 2001: Одисеја у свемиру Стенлија Кубрика, Соларис Андреја Тарковског, Сунце Денија Бојла или Гравитација Алфонса Куарона, у којима напетост лежи у сусрету човека и васионе, микро и макрокосмоса, и трансиендирағу овоземаљске егзистениије, уоквирују и филмски наратив Долазак канадског редитеља Денија Вилнева. Он доследном применом минималистичких стратегија води главну јунакиюу кроз контакт са ванземаљским бићима у домен трансиенденталног искуства. Овај рад износи те стратегије које се у медију филма наслањају на минималистичке поступке аутора у ликовним уметностима (Френк Стела, Барнет 


\section{ВЕСНА ПЕРИЋ}

Њумен, Марк Ротко) као и на поступке минимализма у музици кроз дизајн звука и оригинални soundtrack.

Кључне речи: филм, минимализам, трансценденција, трансиендентални стил, научна фантастика, стазис

\section{Уводна разматрања}

Узвишено мора бити једноставно, лепо може бити украшено и накићено. ${ }^{1}$

Имануел Кант

О минимализму и минималистичким стратегијама у играном филму изненађујуће је мало писано како у англосаксонској и франкофоној литератури тако и у домаћој и регионалној филмској критици, есејистици и теорији. Можда бисмо део оправдања могли наћи у незгодама у вези са самим термином - књижевни теоретичари, попут рецимо, Ким А. Херцингер (Kim A. Herzinger) запажају да минимализам и није прикладан термин и да би било корисно заменити га нечим „одговарајуће описним, нечим што не произилази из сликарства, вајарства, архитектуре или музике"2, тако да бисмо сличну потребу за дефинисањем минимализма могли применити и на филм као уметност. У том смислу, можда би прецизније било говорити о минималистичким стратегијама или стратегијама минимализма у уметничким формама, у овом случају, у наративном филму. Овај рад настоји да, одабиром филмског остварења Долазак (Arrival) из ноторног low brow жанра као што је научна фантастика (и то остварења продуцираног у Холивуду), осветли дистинктну ауторску праксу редитеља средње генерације, Денија Вилнева (Denis Villeneuve), који управо стратегијама минимализма трансцендира филм као производ, филм као индустрију и рорcorn хит узносећи га у готово арт филм достојан традиције европског ауторског филма.

Минимализам у филму као аудиовизуелној уметности подједнако се наслања како на стратегије минимализма у књижевности тако и на минимализам у ликовним уметностима, као и на минимализам у музици. У том смислу, када у границама књижевних приповедних модела и структури мотива посматрамо карактеризацију ликова и драмске сукобе, говорили бисмо о минималистичком филму као уметничком делу где можемо запазити оно што је најближе „хемингвејевској

1 Kant, I. (2002) O lepom i uzvišenom, Nova Pazova: Bonart, str. 18.

2 Herzinger, K. A. (1985) Introduction: On the New Fiction, Mississippi Review, 14(1/2), 17. 7. 2017; http://www.jstor.org/stable/20115378, p. 9. 
редукцији израза и чеховљевској економији приповедања" и „синтаксичкој и мотивској редукцији”. Са друге стране, гледе визуелног израза, у питању би било дело које је лишено „декоративних детаља, у коме је наглашена геометрија а избегнута је експресивна техника"4. Звук и тон на филму такође се могу испостављати минималистичким техникама и бити засновани на минималистичким принципима тишина, репетитивне фразе, рестрикција хармоније, или пак звук снимљен на самом сету као документаристичка, органска белешка.

Декаду шездесетих година прошлог века у сликарству и вајарству обележио је правац Минимализам (који се наводи управо великим словом). Временски са њим коинцидира и филмски минимализам - 1963. године. Енди Ворхол (Andy Warhol) ,режира” филм Cпавање (Sleep) у трајању од 6 сати који приказује Џона Ђорна (John Giorno) како спава. Култни експериментални филм у трајању од 45 минута Таласна дужина (Wavelength) Мајкла Сноуа (Michael Snow) из 1967. сниман је статичном камером у ентеријеру једног стана у коме аутор користи једино технику зумирања. Међутим, ово су експериментални ненаративни филмови, док играни филм (филм фикције) минималистичка средства користи на другачије начине - путем свођења, редукције визуелне и вербалне нарације.

Сам минимализам у филмској уметности можемо лоцирати још раније - како наводи ауторка Сабина Хенсген (Sabine Hänsgen), „развој минималистичких пракси на филму почео је након Другог светског рата када је модерни филм који одражава сопствену темпоралност заменио класични филм радње" опусе аутора као што су Роберт Бресон (Robert Bresson), Jaсуђиро Озу (Yasugiro Ozu), Карл Дрејер (Carl Dreyer), Микеланђело Антониони (Michelangelo Antonioni), Ингмар Бергман (Ingmar Bergman), Андреј Тарковски (Андрей Тарковский), Стенли Кубрик (Stanley Kubrick) а у новије време европских и независних америчких редитеља као што су Бела Tap (Bela Tarr) Александар Сокуров, Андреј Звјагињцев (Андрей Звягинцев), браћа Дарден (Dardenne), Кен Лоуч

3 Гордић Петковић, В. (2011) Минималистички израз и визуелизација нарације у савременој англофоној прози, Годишњак Филозофског факултета у Новом Саду, књ. 36, Нови Сад: Филозофски факултет, стр. $217-220$.

4 Strickland, E. (1993) Minimalism: Origins, Bloomington: Indiana UP, p. 6.

5 Hänsgen, S. Sokurov's Cinematic Minimalism, in: The Cinema of Alexander Sokurov, eds. Beumers, B. and Condee, N. (2011) London/ NY: N. I. B. Tauris, p. 43 


\section{ВЕСНА ПЕРИЋ}

(Ken Loach), Џим Џармуш (Jim Jarmusch), Аки Каурисмаки (Aki Kaurismäki), Гас ван Сант (Gus van Sant), као и редитеља савременог таласа Румунског филма - Кристијан Мунђију (Cristian Mungiu), Кристи Пују (Cristi Puiu), Корнелију Порумбоју (Corneliu Porumboiu). Иако жанровски (мелодрама, социјална драма, психолошки трилер, СФ) и тематски посве различити, за опусе поменутих редитеља јесте карактеристична употреба дугих кадрова, једноставност заплета, документаристичко бележење стварности (минималне интервенције на плану сценографије и костима) или пак хипер-стилизујући одмак од реалности, сведеност глумачког израза, а за многе је карактеристична и „тенденција субверзије" основне одлике филма а то је покрет, успоравање филмских слика, утисак спорости која се постиже „ограничавањем резова у корист дугих, непрекидних кадрова, ограничење покрета камере као и ограничење покрета ликова у сведеној драмској композицији”; такође „филмски медиј овде има сврху контемплативног ангажмана"б. У екстремним случајевима (Бергман, Тарковски, Сокуров), како Хенгсенова наводи, „процес успоравања филмских слика повезан је са редукцијом сложености наратива - упрошћавањем структуре заплета које се граничи са бездогађајношћу"7. Неки теоретичари као што је Андраш Балинт Ковач (Andras Balint Kovacs) налазе да је минимализам на филму карактеристичан за рани модерни период филмске уметност а одликује га „системска редукција експресивних елемената у датом облику" . Семантичко богатство се на тај начин успоставља систематичном варијацијом мотива а не експресивном снагом мотива и појачањем емоционалних ефеката.

Минимализам у уметности одбацује сваки облик редундантности и уопштено представља „стилистичку сведеност у уметностима" тегија свакако је питање стила, а када говоримо о филмском стилу, он према Дејвиду Бордвелу (David Bordwell), филмском теоретичару конструктивистичке оријентације, представља „суставну и истакнуту упорабу техника филмског медија у неком филму" - технике подразумевају мизансцен (инсценацију, светло, глуму и сценографију), технике кадрирања, покрете камере, монтажу и звук, а сам „стил је (...) текстура филмских слика и звукова, посљедица редатељева

\footnotetext{
6 Исто, стр. 44.

7 Исто, стр. 46.

8 Kovacs, A. B. (2007) Screening Modernism: European Art Cinema 19501980, Chicago: Chicago UP, p. 140.

9 Strickland, Е. нав. дело, стр. 6.
} 
избора у одређеним повјесним околностима"10. Такође, можемо прецизирати и „меки стил осветљења”, „стил дугог кадра” или „стил дубинског фокуса”"11.

Сузан Зонтаг (Susan Sontag) у есеју Естетика тишине (Aesthetics of Silence) примећује да уметност која примењује стратегије огољавања, осиромашења, сведености и редукције заправо носи ултимативну амбицију, „жељу да се досегне ослобођена, огромна и свеукупна свесност Бога” ${ }^{\prime 2}$. Иако „више није исповест, уметност је више но икад искупљење, вежба аскетизма". ${ }^{13}$ Минимализам, дакле, интервенцијама на форми директно посеже за пољем духовности. Поједини филмски аутори користе технике и стратегије минимализма (које недвосмислено укључују и аскетски приступ) да би постигли код гледаоца посебан вид искуства, а то је трансцендентно искуство. Оно надилази свакодневно, чулно искуство. Овај појам може подразумевати Трансиендентно као Свето, може подразумевати нешто што је трансиендентално онако како Мирча Елијаде поима хијерофанију, односно манифестацију Светог, а такође може подразумевати трансиенденцију као човеково религиозно искуство. У својој студији Трансцендентални стил на филму: Озу, Бресон, Дрејер (Transcendental Style in Film: Ozu, Bresson, Dreyer), филмски сценариста, редитељ и теоретичар филма, Пол Шредер (Paul Schrader), проматра трансценденталну уметност односно уметност која „одражава Трансцендентно у људском огледалу" чија је функција у томе да „изражава Свето по себи (Трансцендентно) а не да изражава или илуструје света осећања"14. Како Шредер наводи, трансцендентални стил „није инхерентно трансценденталан или религиозан, већ представља начин (тао, у најширем смислу тог појма) приближавања Трансцендентном"15. Шредер наглашава атрибуте неизрецивости и невидљивости којима овај стил тежи коришћењем темпоралних средстава као што су углови камере, дијалог и монтажа, док теме филмова трансценденталног стила уопште не морају бити религиозне. Сам трансцендентални стил на филму Шредер одређује као „општу амблематичну филмску форму која изражава Трансцендентно” и која „увећава мистерију егзистенције и

10 Bordwell, D. (2005) O povijesti filmskog stila, prevod sa engleskog Mirela Škarica, Cambridge/ Zagreb: Harvard UP/ Hrvatski filmski savez, str. 22.

11 Kovacs, А. В. нав. дело, стр. 51.

12 Sontag, S. (1993) Styles of Radical Will, NY: Picador US, p. 12

13 Исто, стр. 6.

14 Schrader, P. (1972) Transcendental Style in Film: Ozu, Bresson, Dreyer, Berkeley: Da Capo Press, pp. 6-7.

15 Исто, стр. 3. 
одбацује конвенционалне интерпретације стварности”; такође, трансцендентални стил „бира ирационализам уместо рационализма, репетицију уместо варијације, свето уместо профаног, божанско уместо људског, интелектуални реализам уместо оптичког реализма, дводимензионални поглед уместо тродимензионалног"; важно је нагласити да су елементи као што је заплет, глумачка интерпетација, камера, музика, дијалог, монтажа, „неекспресивни” и „редуковани на ниво стазиса” односно минимума активности - „попут мисе, трансцендентални стил преображава искуство у ритуал који се понавља"16. Шредер указује на то да трансцендентална уметност показује јасну хијерархију богатих и издашних средстава (меке линије, тродимензионалност, реалистичко портретисање), насупрот сведених (апстракција, дводимензионалност, ригидност), у корист ових потоњих. Стазис представља крајњу инстанцу сведених средстава. Међутим, не може се занемарити употреба издашних средстава јер се тиме одржава заинтересованост публике и тек тако могу доћи до изражаја сведена средства. Конфликт издашног и сведеног дешава се у самом протагонисти који је особа са људским, физичким карактеристикама али се понаша по моделу сведености, хладне стилизације.

Ова Шредерова запажања готово у потпуности можемо применити на изражајна средства која користи редитељ Дени Вилнев (Denis Villeneuve) у филмском наративу чија је протагонисткиња егземплар поменутог конфликта.

\section{Спровођење стратегија минимализма на примеру филма Долазак Денија Вилнева}

Оно чиме ћеш привући пажну индиферентног ока и уха је чистоћа и преиизност. ${ }^{17}$

Роберт Бресон

Долазак (Arrival) из 2016. године је први научнофантастични играни филм канадског франкофоног редитеља Денија Вилнева са скорашњом холивудском репутацијом, који се до сада окушавао у драмама (Олуја/ Maelström; Пожари/ Incendies), психолошким трилерима (Hепријатељ/ Enemy) и акционим трилерима (Заточеници/ Prisoners; Cuкарио/ Sicario). Засигурно је да му је овај филм отворио врата ка режији сиквела култног Истребљивача (Bladerunner) Ридлија Скота (Ridley Scott) - Истребљивач 2049, чија се премијера

16 Исто, стр. 9-11.

17 Bresson, R. (1977) Notes on Cinematography, translated by Jonathan Griffin, NY: Urizen Books, p. 50. 
очекује крајем 2017. године. Филмска прича Долазак највећим делом представља камерни СФ који се наслања на онтолошка питања филмских адаптација као што су, рецимо, 2001: Одисеја у свемиру Стенлија Кубрика (2001: Space Odyssey / Stanley Kubrick) из 1968. или Соларис Андреја Тарковског (Солярис / Андрей Тарковский) из 1972. и оригиналних филмских прича: Амбис Џејмса Камерона (Abyss / James Cameron), из 1989., Сунце Денија Бојла (Sunshine / Danny Boyle) из 2007., Месеи Данкана Џоуса (Moon/ Dunkan Jones) из 2009. или Гравитаичја Алфонса Куарона (Gravity / Alfonso Cuarón) из 2013. године. Иако их дели готово пет деценија, за ове примере филмске научне фантастике карактеристичан је спорији темпо (са изузетком $A$ мбиса који има елементе акционог филма), контемплативне секвенце, камерни израз, сведени мизансцен, контрастрирање крупних планова и тотала, минималистичка сценографиja, а на делу је моделовање унутарњег света протагонисте, драма је у сусрету човека и васионе, микро и макрокосмоса, трансцендирању овоземаљске егзистенције.

Након уводних кадрова-секвенци Доласка праћених voiceoverom главне јунакиње, лингвисткиње Лујзе Бенкс (у тумачењу Ејми Адамс/ Amy Adams) у којима се млада жена игра са својом ћерком у сновиђајној атмосфери, успоставља се наративна садашњост филма, тренутак доласка 12 свемирских бродова ванземаљаца на Земљу. Време радње није прецизно дефинисано али је сугерисана садашња временска инстанца, а не далека будућност. Лујза је професорка лингвистике коју пуковник америчке војске, Вебер (Форест Витакер/ Forest Whitaker), позива да растумачи аудио-белешке говора ванземаљаца из летилице која лебди над локацијом у Монтани. Лујза се придружује војном тиму у коме је и теоријски физичар Јан (Џереми Ренер/ Jeremy Renner) и улази у необичан свемирски брод, налик џиновском облутку од црне седиментне стене. Тим успоставља комуникацију са два ванземаљска бића, хептапода, налик хоботницама, али са 7 пипака. У серији сусрета, Лујза открива да се говорни и писани језик хептапода разликују, а основ комуникације је управо писани језик - скуп семаграма ${ }^{18}$ које хептаподи исписују на стакленој површини мастилом, у облику кругова. Тренутак кризе представља погрешно протумачени

18 У новели, јунакиња Лујза Бенкс каже да семасиографско писање преноси значење које није везано за говорни језик, односно „нема никакве везе између његових компоненти и било ког појединог гласа (...) Оно има сопствени систем правила за грађење реченице, попут визуелне синтаксе која нема никакве везе за синтаксом њиховог говорног језика."; Видети у: Ćang, Т. (2016) Priča tvog života, u: Priče tvog života, prevod sa engleskog Goran Skrobonja, Beograd: Book, str. 107. 
одговор хептапода да су на Земљу дошли да би донели оружје - лидери светских земаља тренутно заузимају борбени став и спремају напад на свемирске бродове. Међутим, није у питању оружје, већ оруће, а заправо дар Земљанима, специфичан хептаподски нелинеарни језик који је у потпуности једино Лујза успела да одгонетне, језик који омогућава истовремено поимање и прошлости, и садашњости и будућности. Захваљујући том дару који је добила у сусрету са хептаподима, Лујзи полази за руком да спречи глобалну катастрофу и напад на ванземаљске бродове комуницирајући на мандаринском језику са кинеским генералом који обуставља војне акције. На личном плану, научивши језик хептапода, Лујза успева да види и своју будућност - све сцене које делују као субјективни Лујзини флешбекови - одрастање са ћерком и њена рана смрт - заправо нису део прошлости, него будућности. Они су флешфорвард онога што тек долази - Лујза ће, иако поседује знање да ће имати ћерку која ће се разболети од непознате болести и умрети, свесно ући у однос са физичаром Јаном и родиће ћерку Хану, не желевши да се лиши радости родитељства, макар и трагичног. Филмска прича представља прилично верну адаптациjу ${ }^{19}$ књижевног предлошка аутора Теда Ћанга (Chiang), СФ новеле Прича твог живота (The Story of Your Life) из 1998. (награђене престижном америчком годишњом књижевном наградом „Небула”) у којој се у монтажним поступцима нелинеарног наратива такође преплићу наративна садашњост и наративна будућност. У филмској пак, дијегези, наративна будућност само се чини као наративна прошлост обојена носталгичним нотама, док је у прозном делу због природе самог језика, граматике и синтаксе, експлицирано будуће време. ${ }^{20}$

Оно што овај филм чини минималистичким на плану форме јесу минималистичка стилска средства и интервенције у структури нарације, одабиру планова и покрета камере, композиција кадра, осветљење и употреба боје у филмској фотографији, костим и звучна нарација (дијегетички и недијегетични звук). Форма минимализма недри атмосферу трансценденталног искуства кроз сусрет човека и не/надземаљског ентитета, једног облика божанског.

19 Аутор сценарија је Ерик Хајсерер (Eric Heisserer), који је сценаристички потписао и СФ филм Створ/ The Thing из 2011., приквел култног Карпентеровог (J. Carpenter) Створа из 1982.

20 "Биће то у кући у Улици Белмонт. Доживећу да видим како се незнанци усељавају у обе куће: ону у којој си зачета и ону у којој си одрасла. Твој тата и ја ћемо прву продати неколико година по твом доласку. Ја ћу другу продати убрзо пошто одеш." - видети у: Ćang, T. nav.delo, str. 92. 


\section{ВЕСНА ПЕРИЋ}

\section{Наративна структура}

Наративна садашњост (сусрет са хептаподима и тумачење њиховог језика) је у трајању од неколико недеља, а наративна будућност (рођење, одрастање и смрт Лујзине кћери) траје неколико година. Преплет две временске равни и нелинеарна наративна структура наизглед одударају од стратегије минимализма у нарацији, међутим, сугерисана је симетрија у којој је почетак исто што и крај, у којој простор - време није линеарно већ је кружно и поима се као сингуларитет, тачка ${ }^{21}$ (sic!) бескрајне густине и закривљеност простор-времена, стање у коме престају да важе закони физике. Сажимање, свођење на тачку која у себи садржи свевременост и свепросторност указује на минимализам који није формалне већ је метафизичке, онтолошке природе - сусрет са (и постајање) Једним, Бићем, Сопством. Све сцене флешфорварда уметнуте у главни наративни ток делују као флешбек до пред сам крај када Лујза у финалном сусрету са хептаподом схвата да је дете које се јавља у њеним визијама заправо дете које ће (се) тек родити. Та суптилна редитељева игра са прошлошћу/будућношћу сугерише разарање линеарне темпоралне структуре а тако и наратива - он није секвенцијални низ већ низ фрагментарних догађаја. Чак и Лујза, као интрадијегетички наратор ${ }^{22}$ у уводној сцени фингираног флешбека каже: „Више нисам сигурна да верујем у почетке и крајеве". Парадоксалан чак и делује тренутак у коме Лујза, други и последњи пут као наратор, говори ћерки (којој? оној из прошлости, као сећања, или будућности? или можемо рећи - из сећања на сопствену будућност): „Ово је тренутак у коме твоја прича почиње" - то је тренутак након последњег сусрета са хептаподима и епифаније, тренутак када схвата да ће управо са Јаном родити дете.

\section{Одабир планова, покрети камере и композиција кадра}

Редитељ Дени Вилнев инсистира на контрастирању тотала у екстеријеру (призорима на терену где се налази лебдећи свемирски брод окружен војном базом и инжењеријом) са тоталима у ентеријеру свемирског брода (који су камерни) а посебно са крупним плановима протагониста, нарочито Лујзе. Тотала у екстеријеру је далеко мање, они су динамични у смислу мизансцена и кретања у самом кадру, док су тотали, средњи планови и крупни планови у ентеријеру брода доминантни, и они су статични. Они на известан начин као да

21 Ова тачка заправо припада црној рупи.

22 Наратор који долази из света дијегезе / филмске приче. 


\section{ВЕСНА ПЕРИЋ}

заустављају, суспендују време. Камера је ретко субјективна, далеко чешће је објективна али контемплативна. Најчешће је Лујза сликана у крупном плану - у сновиђајним сценама са дететом, у сценама на универзитету, а нарочито у сценама контакта - њено лице доминира и када се крије испод заштитне кациге и када је гологлава, како би непосредније осетила контакт. Посебно је индикативна игра симетрије и асиметрије у композицији кадрова унутар свемирског брода са једне стране, у првом сусрету са ванземаљским бићима, тим Земљана је строго визуелно наглашен и одвојен, а од посебног је значаја присуство празног, брисаног простора.

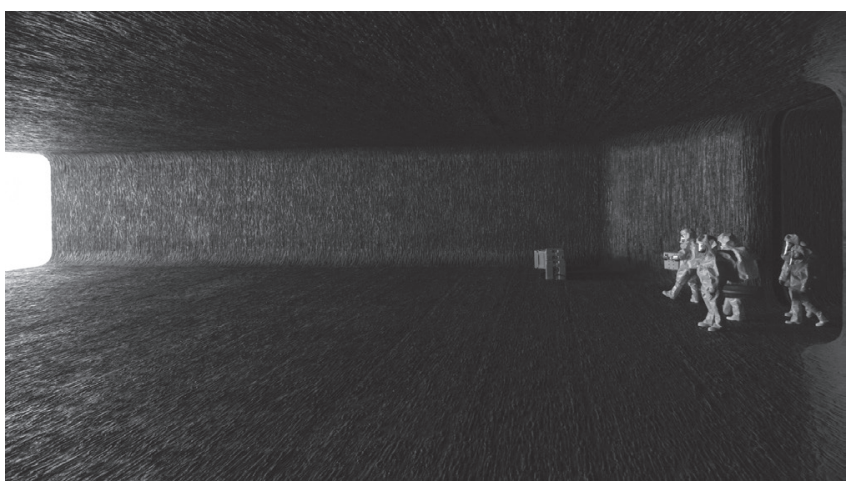

Слика 1 Научни тим у унутрашњости свемирског брода ${ }^{23}$

Тај простор с почетка као да гута људску фигуру, која се у њему губи попут Јоне у утроби кита. Блештеће бели правоуганик светла (односно стакла иза кога се налазе хептаподи) као квалитативно обрнута црна рупа и обрнути Маљевичев црни квадрат на белој позадини, гравитационо али и хипнотички привлачи људске фигуре које се крећу по црној и тамносивој површини. Најпре је сликан као усамљени извор светлости у контрасту са тамном позадином, симетрично, а потом у односу на људску фигуру - тада је сликан широкоуганим објективом којим се постиже дубинска оштрина. Симетрија је приметна и у кадровима у којима лик (Лујза) или оба лика (Лујза и Јан) стоје испред стакла иза кога су два хептапода. Људи су најчешће сликани с леђа а хептаподи увек фронтално, осим у једном једином кадру у финалној сцени сусрета Лујзе са преживелим хептаподом, који је сликан с леђа.

Тренутак Лујзиног финалног силаска у антигравитационо поље лебдећег свемирског брода камера прати у slow motion техници - то је управо тренутак минимума кретања

23 Све фотографије које представљају кадрове из филма Долазак преузете су са сајта Internet Movie Database http://www.imdb.com/title/tt2543164/ mediaindex?ref_=tt_ov_mi_sm 


\section{ВЕСНА ПЕРИЋ}

и активности, тренутак стазиса, након кога ће уследити и Лујзина епифанија, спознаја да визије представљају њену будућност и да је могуће кретати се дуж временске осе у свим смеровима.

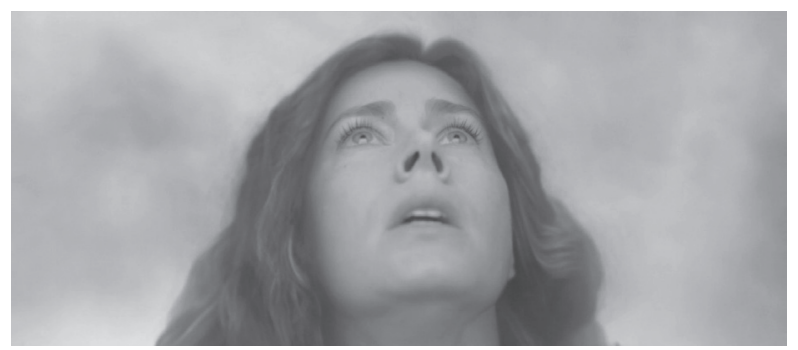

Слика 2 Јунакиња Лујза у тренутку епифаније

Осветьене и боја

У сценама у унутрашњости брода, директор фотографије Бредфорд Јанг (Bradford Young), опредељује се за монохроматски колорит и за камеру тзв. ниског кључа (low key) у коме доминирају тамније боје и штуро осветљење како би се дочарала драматичност сцена и њихова ванвременост. Игра светла и сенки и техника chiaroscuro, карактеристична за Ренесансу и религиозне теме, такође је присутна како би се постигао тај ефекат трансценденталног.

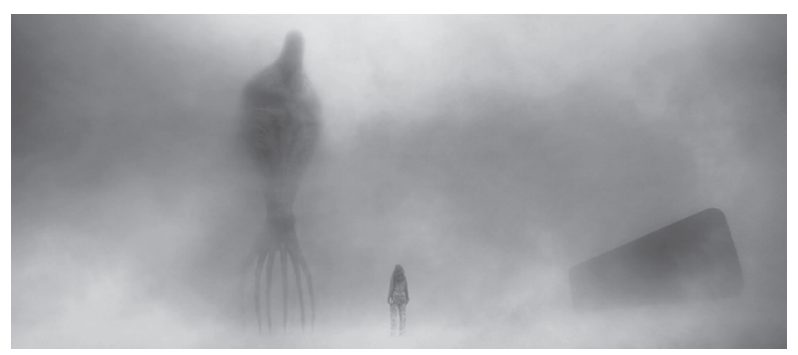

Слика 3 Лујза у свом последњем сусрету са хептаподом Лујза је пре-експонирана (преосветљена) када се нађе лицем у лице са стакленим екраном иза кога су хептаподи. Како се сама филмска прича ближи кулминацији, односно тренутку епифаније и јунакињине спознаје да је докучила сопствену будућност овладавши језиком хептапода, фотографија се ближи монохроматској, сивој. Лујзино заштитно одело јарко наранџасте боје, а такође и њена риђа коса, постају млечно-сиви. Доминирају, дакле, нијансе сивог. Минималистичка употреба оваквих боја и осветљења у филмској фотографији цитира платна великог формата сликара апстрактног експресионизма и минимализма: црно-сиве геометризоване слике Френка Стеле (Frank Stella) - емајл на платну Брак Разума и Прлавштине (A Marriage of Reason and Squalor II) из 1959, затим црно-сиве и нараџасто-зелене слике Марка 
Ротка (Mark Rothko) - Без назива: Црно на сивом (Untitled: Black on Grey) из 1969. и Зелено и наранцасто на ирвеном (Green and Tangerine on Red) из 1956. године које су композиционо сачињене од по два велика хоризонтална црна и сива односно сиво-зелена и наранџаста правоугаоника, а такође и део опуса Ада (Адолфа) Рајнхарта (Ad Reinhardt) познатог по серијама „црних слика” из шездесетих година, једноставних платна обојених у црно (и готово црно). Коначно, у контексту помињаног Шредеровог трансценденталног стила на филму, немогуће је пренебрегнути и јасне визуелне референце на стваралаштво још једног од кључних сликара апстрактног експресионизма а то је Барнет Њумен (Barnett Newman), посебно на његову чувену минималистичку серију под називом Станице до Крста: Зашто си ме оставио? (Stations of the Cross: Lema Sabachtani?) у периоду од 1958. до 1966. године.

Како ауторка Валери Хелштајн (Valerie Helstein) подсећа, није само у питању Исусово страдање с којим се неко суочава путем Станица до Крста (Via Dolorosa), већ како је и сам Њумен (који није био религиозан у традиционалном смислу) нагласио, то је „' страдање сваког човека: страдање које је појединачно, непрекидно, незаустављиво, одлучно - свет без краја” "не издвајајући „Христово појединачно искуство кроз традиционални наратив Станица већ користећи га да би истакао чињеницу да свака особа страда и умире, да смо у нашој посебности (не може се умирати туђом смрћу) сви повезани том судбином, и раздвојени и заједно". ${ }^{24}$ Искусивши будуће рођење и смрт сопственог детета, Лујза у тренутку епифаније доживљава истовремено и бол и радост, спознају симетрије рођења и смрти. Њуменова платна из овог циклуса представљају тамно-сиве и црне линијске облике на светлој површини, који на моменте прелазе у расплинуте структуре, док у филму Долазак ту расплинутост подражава специфично мастило хептапода које се непрекидно морфингује у процесу комуникације ванземаљаца са Лујзом.
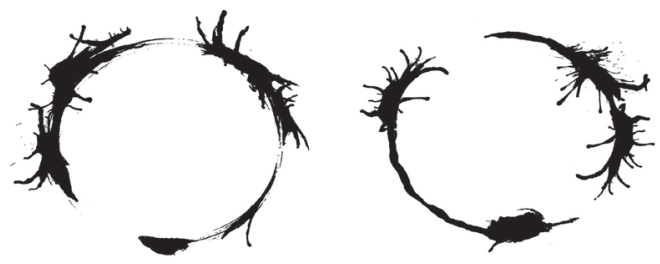

Слика 4 Семасиографско писмо ванземаљаца хептапода

24 Helstein, V. and Barnett, N. (2014) The Stations of the Cross: Lema Sabachtani, in: Conversations: An Online Journal of the Center for the Study of Material and Visual Cultures of Religion, 15. 7. 2017; http://mavcor.yale. edu/conversations/object-narratives/barnett-newman-stations-cross-lema-sabachtani 


\section{ВЕСНА ПЕРИЋ}

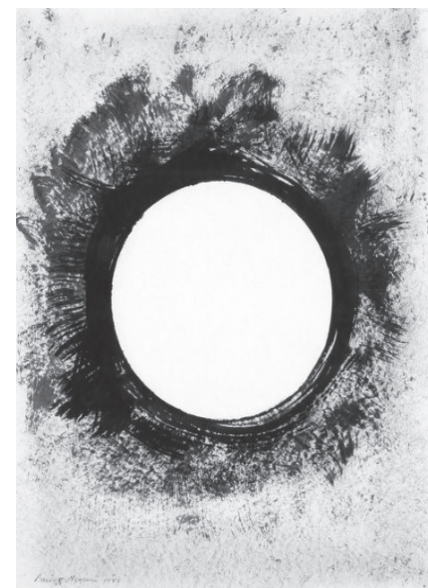

Слика 5 Барнет Њумен, Без наслова, $1946^{25}$

Визуелна структура којој редитељ Дени Вилнев тежи јесте управо структура онога што Барнет Њумен назива плазматичним - плазматични облици (насупрот пластичним у којима доминира богатство боје или неког другог квалитета) су они који покрећу „новог сликара” - боја, линија, облик и простор су елементи који артикулишу његову мисао, и њега интересује тема самог уметничког дела (пејзаж, портрет, механички облик, итд...) а не декоративна природа нпр. облика. ${ }^{26}$ И Вилнев, као и Њуменов „нови сликар”, посеже за плазматичним визуелним изразом на филму - сви видљиви облици - седиментна структура унутрашњости свемирског брода, правоугаони отвор светлости, јајолики монолитни облик свемирског брода, кружни семаграми које исписује хептаподи, сива, црна, бела, наранџаста боја - стапају се у својеврсну „менталну плазму”27 у којој облици у боје дејствују попут симбола.

25 Преузето ca https://www.artsy.net/artist/barnett-newman

26 „У нашој западно-европској култури”, наводи Њумен, „декоративно (оно што желим назвати пластичним елементима) и филозофско (оно што желим назвати плазматичним елементима) се преклапају”. Нови сликар (уметник) овладао је пластичним средствима уметности, „граматиком уметности”, он познаје и „моћне форме”, „богатство боја”, „узбудљиву атмосферу” и све оно што подразумева „квалитет” али осећа да се пластични односно декоративни аспекте његове уметности морају трансцендирати - „истина није питање личне задовољштине, приказ емоционалног искуства; истина је потрага за скривеним значењима живота". Стога придев плазматични подразумева стварање облика који изражавају апстрактну мисао, опипљиве симболе концепта. Плазматично је, иначе, прирођено такозваној „примитивној” уметности - видети у: Newman, B. (1990) Selected Writings, Berkeley/LA: University of California Press, pp. 144-145.

27 Исто, стр. 141. 


\section{Костим}

Лујзина одећа је сведена, готово монохроматска, десатурисаних боја. Једино што одскаче је вибрантни наранџасти костим, односно заштитно одело са кацигом.

Симболика наранџасте боје је вишезначна а понајпре се наводи као „откровење божанске љубави” будући да је присутна, рецимо, у одежди будистичких монаха или пак у велурним крстовима витезова реда Светог Духа и генерално се сматра „симболом вере”28. Када Лујза заједно са истраживачким тимом улази у свемирски брод, група Земљана наликује ходочасницима у одежди боје шафрана, а када јунакиња са себе свлачи наранџасто заштитно одело и кацигу, она остаје у белом, огољена, спремна на контакт са мистериозним бићима иза екрана.

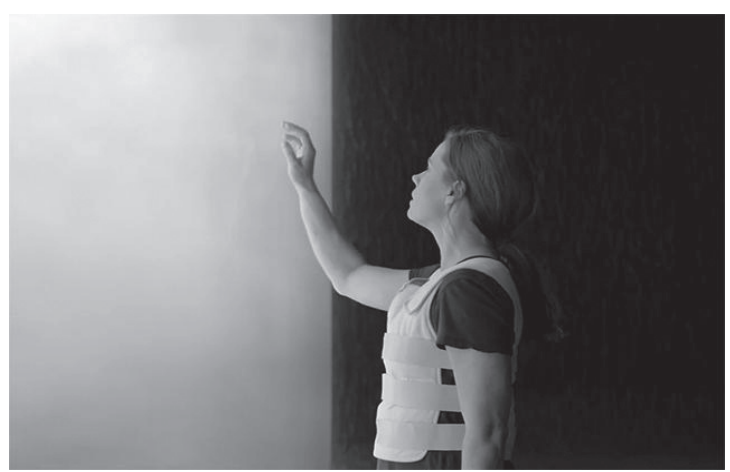

Слика 6 Лујза у контакту са млечним екраном иза кога су хептаподи

\section{Сиенографија}

Принцип минималистичких стратегија у сценографији присутан је доминантно у ентеријеру - од Лујзиног стана сведеног ентеријера са погледом на језеро, преко хладне сценографије у слушаоници универзитета па све до унутрашњости свемирског брода која сугерише празнину и гравитационо привлачење. Екран односно екранска правоугаона структура је доминантна и она је репетитивна - велики стаклени прозори и врата у Лујзином стану, телевизијски екран у слушаоници и преградни екран иза кога се у свемирском броду налазе хептаподи. Једноставност форме одсликава и сам модел свемирског брода који је јајоликог облика, али масивне и монолитне структуре. Са једне стране, та јајоликост упућује на тајну коју свемирски брод носи, на откривање

28 Видети у: Chevalier, J. and Gheerbrant, А. (1997) Dictionaire des symboles, Paris: Robert Laffont, p. 708. 


\section{ВЕСНА ПЕРИЋ}

суштине постојања, контакт са почетком и Постањем ( $a b$ ovo) и крајем који се сустичу у једном, у кружници.

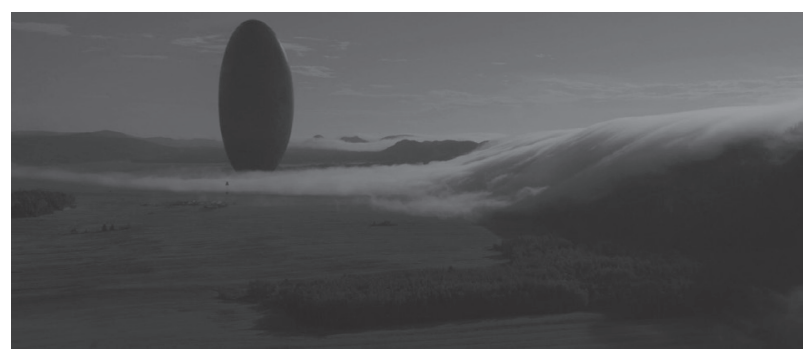

Слика 7 Јајолика монолитна структура лебдећег ванземаљског свемирског брода над Монтаном

Са друге стране, та форма се свакако позива и на амблематични монолит из Кларкове (A. Clark) и Кубрикове Oдисеје као „агенс еволуције, њен надзорник, нека врста путоказа људском напретку". ${ }^{29}$

\section{Звучна наращија}

Редитељ звучно контрастира тренутак доласка ванземаљских бродова са тренутком директног контакта протагониста и ванземаљаца. Информатички шум који креирају звоњаве смарт телефона Лујзиних студената, телевизијски пренос, звук звона за узбуну на универзитету, звук војних хеликоптера и млазњака - све то имплодира у тишину приликом уласка у свемирски брод а затим лагано та тишина постаје бруј. Звук који се том приликом чује наликује интраутералној звучној кулиси, оној коју фетус може чути у утерусу у утроби мајке. То понирање јунака у унутрашњост свемирског брода звучно подражава и сугерише пренатално стање. Дизајнер звука, Дејв Вајтхед (Dave Whitehead), употребио је дисонантни интервал - малу секунду и кварту, које продукује дувачки инструмент новозеландских урођеника, Маора, као звук који емитују хептаподи у тим тренуцима контакта људи и ванземаљаца. Сама филмска музика, soundtrack, коју је компоновао исландски композитор Јохан Јохансон (Jóhann Jóhannsson) заснована је на вокалима (хорским и соло) - коришћењем „гласа као водећег инструмента у филму који се примарно тиче језика и комуникације" а сами извођачи производе „углавном самогласнике без неког одређеног значаја, и то звучи као језик који је у стадијуму лаганог формирања." ${ }^{30}$ Репетитивни ритмички музички

29 Denijels, D. (1969) 2001: novi mit, Filmske sveske br. 9, godina II, Beograd: Institut za film, str. 578.

30 Calvario, L. 'Arrival' Score: Listen to Jóhann Jóhannsson's Moving Compositions, 11. novembar 2016., 15. jul 2017; http://www.indiewire.co$\mathrm{m} / 2016 / 11 /$ arrival-soundtrack-listen-johann-johannsson-score-1201745666/ 
namepни, staccato вокали, ефекат дрона (држаног базичног тона) који упућује на архаичне, готово пре-егзистентне облике, доприносе атмосфери трансцендентног путовања јунака. Прибегавање оваквим сведеним музичким фразама и темама наслања се свакако и на чувену минималистичку музичку тему, дурски мотив из Спилберговог (Steven Spielberg) остварења Блиски сусрети треће врсте (Close Encounters of the Third Kind) која се састоји од свега пет тонова који су основ комуникације са ванземаљском расом.

\section{Закључак}

Сви елементи филма Долазак - наративна структура, одабир планова, покрети камере, композиција кадра, осветљење и боја, костим и сценографија, и звучна нарација - својим минималистичким формама јесу у служби путовања главне јунакиње, њене трајекторије трансценденције и њеног трансценденталног искуства и спознаје. То је истовремено и екстатично искуство. Редитељ Дени Вилнев доследно спроводи стратегије минимализма доминантно кроз визуелни али и кроз аудитивни регистар, доводећи филмску причу у тренутку кулминације у ниво стазиса - кулминација није експлозија већ имплозија, тренутак безвремености и свевремености, успорен - боја бледи, лице је у крупном плану, у екстази, у додиру са божанским ентитетом. Улазак у труп свемирског брода је и силазак у порођајни канал - гледалац је, баш као и протагонисткиња, хипнотички увучен у сиву измаглицу, у звучној опни брујања и дронова, доведен до граница свог физичког тела. Иако делује у оквиру холивудске индустрије, Вилнев несумљиво носи ауторски рукопис који се опире синтагми „биоскопски филм” - он нуди превазилажење улоге конзумента потрошне робе, филма као производа, и то узнемирујућим питањима (о) човечанству „Због чега су они овде?”з1 , шта човек може открити о себи, о својим границама у простору и времену, и коначно, шта је у таквом просторвремену питање слободне воље.

Филм као уметност и као медиј носи „ризик презасићења чула" стога су посебно значајни они филмски текстови који одударају од овакве формуле отварајући гледаоцу текстуални простор ,лаганим темпом, својим кинематографским и наративним минимализмом, да би се одједном суочио са фрагментацијом и позивом да учествује у потенцијалној реконструкцији фрагмената". 32

31 Питање исписано на плакату филма Долазак.

32 Phillips, T. (2013) The Subject Of Minimalism: On Aesthetic, Agency and Becoming, NY: Palgrave Macmillan, p. 8. 


\section{ВЕСНА ПЕРИЋ}

Долазак Денија Вилнева засигурно спада у ред таквих филмских текстова.

\section{ЛИТЕРАТУРА:}

Bordwell, D. (2005) O povijesti filmskog stila, prevod sa engleskog Mirela Škarica, Cambridge/ Zagreb: Harvard UP/ Hrvatski filmski savez.

Bresson, R. (1977) Notes on Cinematography, translated by Jonathan Griffin, NY: Urizen Books.

Calvario, L. 'Arrival' Score: Listen to Jóhann Jóhannsson's Moving Compositions, 11. novembar 2016., 15. jul 2017., http://www.indiewire.com/2016/11/arrival-soundtrack-listen-johann-johannsson-score-1201745666/

Chevalier, J. and Gheerbrant, A. (1997) Dictionaire des symboles, Paris: Robert Laffont.

Ćang, T. (2016) Priča tvog života u Priče tvog života, prevod sa engleskog Goran Skrobonja, Beograd: Book.

Denijels, D. (1969) 2001: novi mit, Filmske sveske br. 9, godina II, Beograd: Institut za film.

Гордић Петковић, В. (2011) Минималистички израз и визуелизација нарације у савременој англофоној прози, Годишъак Филозофског факултета у Новом Саду, књ. 36, Нови Сад: Филозофски факултет.

Hänsgen, S. Sokurov's Cinematic Minimalism, in: The Cinema of Alexander Sokurov, eds. Beumers, B. and Condee, N. (2011) London/ NY: N. I.B. Tauris.

Helstein, V. Barnett Newman, The Stations of the Cross: Lema Sabachtani, in: Conversations: An Online Journal of the Center for the Study of Material and Visual Cultures of Religion (2014), 15. 7. 2017, http://mavcor.yale.edu/conversations/object-narratives/barnett-newman-stations-cross-lema-sabachtani

Herzinger, K. (1985) Introduction: On the New Fiction. Mississippi Review, 14(1/2), 17. 7. 2017., http://www.jstor.org/stable/20115378

Kovacs, A. B. (2007) Screening Modernism: European Art Cinema 1950-1980, Chicago: Chicago UP.

Newman, B. (1990) Selected Writings, Berkeley/LA: University of California Press.

Phillips, T. (2013) The Subject Of Minimalism: On Aesthetic, Agency and Becoming, NY: Palgrave Macmillan.

Schrader, P. (1972) Transcendental Style in Film: Ozu, Bresson, Dreyer, Berkeley: Da Capo Press.

Sontag, S. (1993) Styles of Radical Will, NY: Picador US.

Strickland, E. (1993) Minimalism: Origins, Bloomington: Indiana UP. 


\section{ВЕСНА ПЕРИЋ}

\section{Филмографија:}

Sleep (1963), Andy Warhol (USA)

Wavelength (1967), Michael Snow (USA)

2001: A Space Odyssey (1968), Stanley Kubrick (UK/USA)

Солярис (1972), Андрей Тарковский (СССР)

Close Encounters of the Third Kind (1977), Steven Spielberg (USA)

Abyss (1989), James Cameron (USA)

Maelström (2000), Denis Villeneuve (CAN)

Sunshine (2007), Danny Boyle (UK/USA)

Moon (2009), Dunkan Jones (USA)

Incendies (2010), Denis Villeneuve (CAN/ FR)

Enemy (2013), Denis Villeneuve (USA)

Prisoners (2013), Denis Villeneuve (USA)

Gravity (2013), Alfonso Cuaron (UK/USA)

Sicario (2015), Denis Villeneuve (USA)

Arrival (2016), Denis Villeneuve (USA) 


\title{
ВЕСНА ПЕРИЋ
}

\author{
Vesna Perić \\ RTS, Radio Belgrade, Belgrade
STRATEGIES OF FILM MINIMALISM AND THE ARRIVAL BY DENIS VILLENEUVE \\ TRANSCENDENTAL IN THE SCIENCE FICTION FILM
}

\begin{abstract}
Science fiction as a film genre often employs strategies of minimalism - through elements such as narrative structure, shots, camera angles, camera movement, composition, lighting, colour, costume, set design and sound narration. The minimalistic technique manifests transcendental style - the way Paul Schrader uses this term in his study Transcendental Style in Film: Ozu, Bresson, Dreyer (although it doesn't cover this genre). This technique involves the principle of reduction in all possible forms, as well as repetition, abandoning decorative details and expressive techniques, conveying the film narrative to a stasis a point where sparse means collide. Ontological query posed by SF dramas such as Kubrick's 2001: A Space Odyssey, Tarkovsky's Solaris, Danny Boyle's Sunshine, Alfonso Cuarón's Gravity, where suspense derives from human contact with the Universe and from transcendence of earthly existence, also frames the film narrative Arrival directed by a Canadian filmmaker Denis Villeneuve. Consistently executing minimalistic strategies, Villeneuve guides his female protagonist through contact with extra-terrestrial beings into the sphere of transcendental experience. This paper interprets those strategies in a film medium which follow minimalistic practices of painters and visual artists (Frank Stella, Barnett Newman, Mark Rothko and similar) as well as techniques of music minimalism through sound design and original soundtrack. The protagonist's contact with heptapods (extra-terrestrials with seven limbs) not only results in deciphering their written language but in her own epiphany: going through transcendental experience she is given a gift of foreseeing her future and making life changing decisions.
\end{abstract}

Key words: film, minimalism, transcendence, transcendental style, science fiction, stasis 